\title{
Paradigms to Drive Higher Education 4.0
}

\author{
Pauline Swee-Choo Goh \\ Sultan Idris Education University, Malaysia \\ Perak, Malaysia \\ Norwaliza Abdul-Wahab \\ Sultan Idris Education University, Malaysia \\ Perak, Malaysia
}

\begin{abstract}
This paper discusses two important paradigms that should to be present to fuel the needs of today's technology driven environment roles of teacher education that must be changed and the eco-system of the learning institutions itself. Access to education has moved away from the traditional campus environment to a technology driven platform. New tools and technologies have provided borderless and flexible learning. Change in education is undergoing at an unprecedented speed never experienced before. Teachers are the frontliners towards helping children reach their potential, however this paper argues that current teaching staff may lack the pedagogy to teach in this 'digitised' world and to be competent to lead their ward into the new era of technology driven experiences. Therefore, reforms in the content and teaching of student teachers become imperative. The second paradigm looks at the institutions of higher learning itself. The paper asserts that these institutions need to move away from the traditional way of imparting knowledge and conducting research to a new way of doing which provides autonomy to educators and learners through technology. Teaching and learning approaches, innovation, and valueadded student experiences which use technology are all part of the concept of Higher Education 4.0.
\end{abstract}

Keywords: Higher education 4.0; concept of 'readiness'; technology driven environment; higher education reforms; student learning

\section{Introduction}

The prospect for higher education to lead and transform teaching and learning in the era of higher education 4.0 (H.E 4.0) in readiness for the evolutionary Industrial 4.0 (I.R 4.0) has been a topic of discussion not only in developed countries, but in all emerging economies of the world (Salmon, 2019). The difference between a developed economy and an emerging economy is that the former may be more ready to adopt processes of H.E 4.0 readiness if compared to other emerging economies (Dadios et al., 2018). These emerging economies 
may face substantial challenges with evolving technology such as artificial intelligence, Massive Open Online Courses (MOCC), virtual reality (VR) and 'The Internet of Things' - all part of the delivery of H.E 4.0, but important concepts to get equipped for the I.R 4.0. For many emerging economies, as it competes in the world arena, the adoption of H.E 4.0 may be lagging and therein arise a 'digital-divide' between these economies (Prensky, 2001; Shenglin et al., 2017).

Malaysia, as an emerging economy, intends to be prepared and equipped for the I.R 4.0 through a quality H.E 4.0. The drive towards this aim has been part of the country's Education Blueprint 2015-2025 and the 2050 National Transformation (TN50) aspiration and the Higher Education 4.0 (H.E 4.0) policies (Rozana, 2017). To achieve the goals of reforming teaching and learning within the Malaysian higher education institutions, there is a need to reach a minimum level of readiness. Readiness is judged by the institutions' potential to contribute and be involved in new opportunities or directions of learning and teaching in an increasingly networked world ("Readiness for the Networked World", n.d). However, complexity and confusion arise within all levels of higher education, thus creating uncertainty about respective institutional capabilities, and adequate strategies to assess the success and readiness of H.E 4.0. These technological advances in H.E 4.0 takes place within individual institutions rather than consistently implemented throughout the higher education institutions in Malaysia. The smaller or newer higher education institutions may be uncertain about their readiness required for implementing new technological advances and the overall impact on their educational objectives. On the other hand, the newer or smaller institutions may experience doubts in transforming their own educational efforts with regards to the I.R 4.0 vision and therefore miss opportunities towards improving or refit curriculum, programs, academic training, projects and technologies (Gaertner et al., 2016). To overcome the growing complexity and uncertainty, new strategies and paradigms are needed to provide guidance and support to help determine H.E 4.0 readiness (and success) (Gaertner et al., 2016). Therefore, this article would like to take a 'first step' and look at some of the new perspectives or new ideas that is necessary to meet the changing higher education landscape of today. In addition, the article hopes to provide some suggestions as to how higher education institutions of today can prepare themselves and for their students in readiness for Industrial Revolution 4.0. This paper sets out to discuss some of the paradigms that are needed for higher education institutions to be ready and to remain relevant in the era of rapid changes.

\section{Concept of 'readiness'}

The concept of 'Readiness' is not new and has been identified as an emerging trend that education needs to address to be relevant and maybe, even to survive (Ruban, 2017). In "On Track: Redefining Readiness in Education and the Workplace" (Gaertner et al., 2016), describes three approaches to promoting readiness. The three approaches focus on different aspects of readiness - careful assessment, actionable interventions, and access. An example of the first approach is the college readiness index which measures both academic 
competencies like GPAs and test scores and "environmental factors" like family circumstances and school characteristics. It gives a big picture of the students' readiness for higher education.

On the other hand, "The Conley Readiness Index" (example of an actionable interventions), evaluates students' meta-cognitive abilities like "Learning Skills" and "Career Transition Skills", reporting on students' academic strengths and weaknesses. These profiles enable students to better understand their strengths and to correct weaknesses. To enable students (and potential employees) to understand the strength of their maturity and adaptability when faced with difficulties, the "GRIT Mindset" readiness index was developed (example of access). This index provides access to students and employees to gauge their own adaptability and change accordingly. Nevertheless, it can be argued that there is an oversight towards career success in the new Fourth Industrial Revolution (I.R 4.0). It is transforming human activities: the way things are made; the way resources are used; the way of communicating and interacting as humans; the way a country is governed - its speed and scope is something many have not predicted would happen so soon and so fast. Many educational institutions are left unprepared ("The world is changing", 2018). All through the decades, the industry has somewhat shaped the direction of education.

Institutions of learning need to mount greater initiatives to respond to this new era (satiated with artificial intelligence, Massive Open Online Courses, virtual reality and 'The Internet of Things') and to more efficiently utilize their educational resources and strategies to produce future students who are ready to embrace and to enter the realms of I.R 4.0, that goes beyond CGPA, test scores, and the number of A's (Rozana, 2017). Machado (2007) argues that higher education institutions could lack the ability to create and develop specialists (administrators, students, preservice teachers, educators) for opportunities in the realm of e-readiness and information technologies. E-readiness is the use of information and knowledge (Machado, 2007).

The measurement of e-readiness is generally judged by how advance an institution adopted the use of technology together with its applications ("Readiness for the Networked World", n.d). E-readiness can also be described as an institution that has the necessary physical infrastructure (high bandwidth, reliability, and affordable prices). The school or institution has integrated current technology throughout for student to use in their everyday life and is also a subject taught in schools ("Readiness for the Networked World", n.d). Preparing students for the information and knowledge society becomes very urgent. Therefore, this paper asserts that higher education must aim towards enriching student experience and support each student's needs. In this revolutionary era, higher education must strive to align its learning and teaching environment to enrich students' experiences. This can be done from the day students enter the institutions, providing a conducive learning and teaching environment (no less through technology) and seeing them until their completion. Higher education has two roads to take - embrace new technological opportunities and succeed or be complacent, remain status quo and perish. The next section looks at some 
suggestions a higher learning institution might need to consider to keep pace with the changing times and the arrival of H.E 4.0.

\section{Paradigm shifts in higher education in the era of H.E 4.0}

Any transformation towards a shift in paradigm or doing something differently is never easy and often uneven. Nevertheless, institutions of higher learning in Malaysia must act swiftly and adapt to changes to remain relevant for its own future. The suggestions for this paradigm shift revolves around two elements: a) teacher education; and b) the eco-system of the institutions itself. It starts off with the role of teacher education. The authors feel that teachers are at the forefront of education, they are responsible for bringing to the fore the success of every students in school, right to tertiary education. This paper argues that it is these two elements that lay the foundation for the institutions of higher learning in the era of H.E.4.0.

\subsection{The important role of teacher education institutions}

Malaysia has its education following closely to the British system of education. The administrators from Britain took over the then named Federation of Malaya which consisted of 11 peninsular states. In around 1956, the leaders from the Federation of Malaya and the United Kingdom came to an agreement that Malaya should be granted independence by August 1957 headed by the late Tengku Abdul Rahman. Malaysia gained independence on 31 August 1957 through peaceful negotiations and talks. Nevertheless, the legacy of the rules from United Kingdom remained till today and has permeated in every area of government, and especially, education.

Education starts from the preschool at ages $4-6$, and then at age 7 , children commence their primary school education. Primary school education runs for six years. Secondary school education has two levels - the three years lower secondary education and two years upper secondary level. At the end of five years of secondary education, a common national examination is held. After completion of the secondary school education, students can either take one or two years of post-secondary education. These are courses to prepare these students for the university. Some students can also choose the pathway to teacher education either in the teacher education institutions or in the universities which offer the Bachelor of Education.

Teacher education in Malaysia had its humble beginning in 1922 and was the first teacher education recorded to prepare teachers in Malaysia. Since then, teacher education has evolved to meet the needs of the country and has made many transformations through numerous policies and strategies. To help in the reforms of teacher education, the National Philosophy of Education was formulated to drive new institutions that formed after 1922. Although, initially, the Ministry of Education Malaysia (MoE) had full control of all the teacher education institutions, when new universities (both public and private universities) began to form, these universities also had their own faculty of education to train new teachers. 
Two different pathways of teacher training exist to this day - the MoE, has sole control of the teacher education institutions through its Teacher Education Division (TED), while the universities are given autonomy to develop their own teacher training curriculum, but following closely to the visions and aims of the National Philosophy of Education. The universities confer the Bachelor of Education after four years. These universities also conduct postgraduate studies for those who wish to pursue higher degrees (Goh \& Blake, 2015).

According to Goh and Wong (2015), teacher education has been slow to embrace and adapt to the rate of change towards learning and teaching. Teachers have increasingly been let down by the preparation they received and thus failed to meet the expectation of various educational stakeholders (Goh \& Blake, 2015). Efforts towards improving teacher education have been rather silent although the Malaysian Education Blueprint clearly states the need to advance teacher quality in schools. Concerted effort should also aim to elevate the standard of teacher education. New teacher education curricula which should emphasize the thrusts envisaged in the Malaysian National Philosophy of Education, selection procedure through a common admission test, and evaluation practices have not been upgraded. The baby-boomers and Gen Xers who are world leaders now may not be savvy in the use of technology. Instead they are the end users from the creative development of their successive generation - the Gen Y, Z and the millennials. Government, through the Ministry of Education, must be aware that the current teaching staff may lack the pedagogy to teach in this 'digitised' world and to be competent to lead future teachers into the new era of technology driven environment. Authorities and institutions should prioritize flexible approaches that allow context and discipline-specific responses rather than onesize-fits-all solutions (Goh \& Blake, 2015; Goh \& Wong, 2015).

Although research have shown that teacher education provides the avenue for teachers to learn teaching pedagogies, understanding, awareness of student learning and the readiness to be effective teachers in the classrooms, improvements in teacher education need to happen (Goh, 2019a). A qualitative study by Goh and Wong (2014) of novice teachers in their first three years of teaching find them dissatisfied about the over emphasis on theory of education during their campus learning. These novice teachers have voiced that there should be greater importance in the practical interaction between theory and practice. Student teachers in practicum felt that they were somewhat unprepared to help student learn. Some new teachers are not able to move beyond superficial teaching towards using more sophisticated skills to promote effective learning within the learning environment (Goh \& Matthews, 2011).

Student teachers need a wide range of knowledge and experiences and at the same time the ability to incorporate them into their practices in a meaningful way (Goh, 2019b), something not typically found in teacher preparation programs. Students of the classroom today are multi-racial and multi diverse in their learning abilities (Arend, 2014). As such, the approaches to learning and teaching require new skills and pedagogical know-how. Handbooks on teacher education reflect the magnitude of that knowledge. 
From a sociological point of view, student teachers need experiences that can deepen and broaden their understanding of cultures and the social problems that invade a classroom (Arends, 2014). Beyond cultural and social issues, there is also the need to be aware of the ethical responsibilities of teaching. From the perspective of educational psychology, student teachers must ensure they have the ability to reflect on new research about learning and teaching. New developments in educational psychology offer valuable insights into the conceptions of teaching that are consistent with the more complex view of a learner. No more are learners restrictively viewed from the perspective of their intelligence which has limited the expansion of the learner's potential and motivation (Gardner, 2011). To ensure that student teachers develop the knowledge that will enable them to represent subject matter in meaningful and powerful ways that challenge their learners, teacher education curriculum must be constructed to integrate content with practice (Goh, Canrinus \& Wong, 2019). Student teachers must graduate with the ability to act on their knowledge and evaluate their experiences in terms of their developing visions of their role and responsibilities as teachers (Goh \& Canrinus, 2019). It is easier written than done. Although efforts to change and improve teacher education will pose significant challenges for teacher educators, not to do so would be akin to leaving teacher education at the periphery of the Education Blueprint instead of moving it the centre where it should be. For the sakes of future teachers, teacher educators need to explore the many facets of teaching and derive new approaches for learning and teaching. There is a need to embrace innovation in teaching and provide flexibility to allow new approaches to be experimented and formed. The wave of education reforms after the 14th general election in Malaysia and with the re-enactment of the Education Blueprint after the 18th general election provide the opportunity to part with the past and begin new chapters in teacher education. However, for the Education Blueprint or any reforms to work - the eco-system of the institutions of higher learning must be ready.

\subsection{Eco-system of the learning institutions}

\subsubsection{The learning environment}

Learning institutions of the future must move away from a learning environment which provides students with a predictable time frame of completion. Most universities now, including teacher preparation institutions, have a four year duration. Instead, there must be flexibility in the time frame for students, for example, students should be 'life-long' learners. There exist flexibility for the student to come back and to take courses over many years instead of just the conventional four years. These same students are also sharing their life experiences when they attend classes. There is a symbiotic learning environment among new and returning students in perpetuity. As Prof. Asma, the Vice-Chancellor of Universiti Sains succinctly stated, "There is a rise in "nontraditional" students in the workforce who now want to learn ... they have varying levels of education and experience, they cannot afford four years to complete a university degree, want to learn at their own time and pace, and it has to be personalised to their needs" (Menon, 2019). 
Malaysia has touted life-long learning to allow continuous learning and relearning (Menon, 2015). However, this aim can only be met if institutions of higher learning allow these students multiple entry and exit points in their lives. Words such as re-skill and upskill will not happen if the doors of the universities are not flexible or the admission/enrolment procedures are rigid and static. New ways of learning, through blended learning, flip-classroom must also be made accessible to allow distant learning and interaction among students. Institutions of higher learning must evolve to cater to the needs the students' learning process through technology. The benefits to the institutions are high - not only will cost be brought down, the learning institutions can now encompass a wider group of people not restricted to only Malaysia. There is an element of 'space' and 'time' and a spread of multiple sharing among students of the world.

More often than note, the traditional way of learning is slowing losing its lustre. There is an advent towards online distance learning or ODL (Phelps \& Vlachopoulos, 2019) and modular learning (Karal \& Cebi, 2012; Thompson et al., 2010). ODL enables a student to access resources through a synchronous learning with web video conferencing. A note of caution though, universities must be ready with a robust framework for either an ODL environment or modular learning. There must be stringent but impartial and independent assessment of a student's work. Nevertheless, both ODL and modular learning provides the opportunity for universities to look beyond a traditional classroom and not to be bordered by fixed curriculum (Thompson et al., 2010). Rather, ODL and modular learning provides the avenue for students to select from a basket of programs more suited to their needs and pace.

Yet, with this advent of ODL and modular format of learning, educators need to be maintaining the quality of education through this mode. It is very easy to forget that although students are at a distant, their achievement through thorough assessments is still very important. Industry players must feel the confidence that as universities move away from the traditional face-to-face monitoring system, the platform for ODL or modular learning remains robust and of high standards (Latchem, 2017). In other words, accreditation bodies (an example in Malaysia is the Malaysian Qualifications Agency) must be even more diligent at ensuring universities do no 'take a short cut' but that universities continuously ensure the high standards of learning, teaching and assessment they have always set out to be.

\subsubsection{Employability}

There appears to be a mismatch between what the industry or the outside world needs versus what the learning institution are teaching in Malaysia. This is not a phenomenon that is distinct to Malaysia but to the world (Abdul Hamid, Islam \& Noor Hazilah, 2014). Challenges abound for the students who will leave the universities today. According to Altbach, Reisberg and Rumbley (2019), as soon as the students leave the university, the skills that are taught would have changed. Employability or rather germane employability is key for today's graduates. The University of today must address this crucial challenge. 
Graduates upon leaving universities suddenly find themselves unable to obtain employment or many have found that the rapid rise and changes in technology have made them obsolete as soon as they leave the universities. Universities are not keeping pace with what is happening with the fast evolving technology (Altbach, Reisberg \& Rumbley, 2019). Could universities have failed to seize the opportunities to prepare their students for the changing working arena? Universities need to have a mind-set revolution - no more are the static incampus education enough. There must a focus on skills to prepare their students to be solvers, decision makers and analytical thinkers - all skills which are necessary to 'survive' in the industrial revolution dynamics (Altbach, Reisberg \& Rumbley, 2019). Students must be made confident that they are not obsolete or redundant with universities courses more suited for a forgotten era.

In an article in The New Straits Times of Malaysia (Mustafa, 2019), Dr Ahmad Shuhaimi Abu Bakar, an academic at the University of Malaya, acknowledges that industry partnership would assist students and even new graduates to develop their competency 'in-situ'. Benefits of industry engagement would also be the sharing of what is actually needed out there versus what in-campus learning are offering. Curriculum can be designed and developed together with the institutions of higher learning for programs more specific to the current needs. Students are provided the platform to learn from industry players, assessed by 'bosses' of these industries and at the same time get merits for work done in the real world but yet enrolled as university students. The added advantage of two worlds - campus learning and corporate learning provide more agility for the students and academics with a rapidly changing technology base, the 'hunger' for everything IT, and staying more connected. However, a note of caution. With the excitement of being connected and things IT, there is also the need to be mindful of pitfalls especially with proper monitoring and control over learning. There is a fear that education can get waylaid over IT and how new learning is being conducted that quality of education gets diluted. Proper assessment and outcomes that can impact society must be part of any new way of learning. Although, some may argue against standardization of assessment, teaching and learning, educators still need to be mindful of maintaining education and not at the expense of monetary gains only (Anane, 2014).

\subsubsection{Technology's role}

With the rapid advancement in technology, government finds themselves grappling with graduates who, upon, completion are unable to find employment (Altbach, Reisberg \& Rumbley, 2019). The burden falls upon education of higher learning which have failed to keep pace with the ever evolving technology. Institutions of higher learning are either in denial about the rapid changes happening around them or lack the capability to transform or the will-power to reform to current situation. It is not enough for institutions of higher learning to merely provide basic skills for their students but to better prepare their students to be ready for the technology race by being problem-solvers, being critical and analytical thinkers. The rate of 'obsolete-ness' rises with every year an institution 
delays to equip their students with the complex skills needed for the rising industrial revolution.

Undoubtedly, technology is here to stay with it playing a very important role in the quick rise towards industrial revolution. Schwab (2015) aptly warns that: "The speed of current breakthroughs has no historical precedent. When compared with previous industrial revolutions, the Fourth is evolving at an exponential rather than a linear pace. Moreover, it is disrupting almost every industry in every country. And the breadth and depth of these changes herald the transformation of entire systems of production, management, and governance." (Schwab, 2015). Nevertheless, universities should also seize upon the opportunity to harness its use to drive innovation in learning and teaching. As Schwab rightly comments, the aspirations of students and teaching staff can be met through integrating activities run by technology. A 'digital framework' that can facilitate learning and teaching activities from new enrolment, maintaining records, facilitation assessments, right through issuance of students certificate - all with ease.

With the popularity of 'personalized learning', it is here that technology can play its most important role (Darling-Hammond, Flook, Cook-Harvey, Barron \& Osher, 2019). One, the traditional learning environment are being overtaken with new program offerings through blended learning, self-driven MOOCs and other online courses. These new approaches to learning accord flexible learning time to students. Two, technology allows universities to offer courses that are more varied and are able to enrol students 'without borders'. There are no constrains to where students come from. The advent of complex, yet easy to use, learning tools has enabled universities to overcome the burden of providing physical classrooms. However, it must be noted that MOOCs and online courses are not competing with campus learning. Rather, MOOCs offer multiple avenues for the universities to plan, complement and supplement what is already there. Three, once, where higher learning have been the privilege of the rich and elite, students are now given better choices to obtain higher degree. There are better equity of access to higher education (McCowan, 2016). Lastly, in addition, not only are students accorded more flexibility in time and cost through MOOCs and online learning, they emerge more ready and confident with the real world situation. Knowledge obtained would contain skills that are looked for by employers. Technology has enabled universities to impact learning and teachers and at the same time provide the life skills needed for application in life's reality (Jackman, 2018).

\subsubsection{Research and innovation}

For universities to be ready to prepare their students for the future environment, these institutions themselves must be equipped for new knowledge and learning. Universities are the 'incubation' centres for innovation and creation of future intelligence. In addition, it is the universities who will be tasked by the government of the country to be the leaders of research and innovation. Malaysia has put in place every avenue to encourage the universities to be competitive in the world arena to take the country into greater heights towards 
development, innovation and being less reliant on low skilled labour and labour intensive employments (Malaysia Education Blueprint 2013-2025, 2018). However, Malaysia universities are still falling behind in research and innovative outputs when compared to other developed nations, despite the millions in research grants being given to the universities (Cornell University, INSEAD, \& WIPO, 2015). Research must be focused to produce outcomes that can be applied or able to solve challenges related to real problems within the country. It is not to say that theoretical research are unimportant, but such research must have a place in real world settings as universities no longer have the luxury of lounging in slow developmental studies while the world races towards a demanding and exacting environment. It is also no longer a luxury for a university to be isolated and to bask in its own laurel but must work towards networking with other reputable universities. Integrating knowledge and sharing new technological know-how is now mandatory for a university to advance and evolve - and should be made a mantra for any research being carried out.

\section{Conclusion}

Students today have veered far from the days of television and analogue radio. 'Streaming' is a word quite alien to their grandparents and even their parents. This generation of 'digital connoisseurs' has gone beyond looking at physical books for information. Instead they are almost perpetually on the internet. They are totally at ease with everything that is digital. With this new generation of 'digital connoisseurs' - learning must also change. At almost the same time, these 'digital connoisseurs' have rapidly changed the educational landscape with their prowess with Artificial Intelligence, Internet of Things and Analytics. Therefore, no more can higher education take a complacent stance and be left behind in educating this new generation. Because learning is now borderless, institutions of higher learning must also be as quick to transform and move away from more conservative learning models. Instead these institutions must be quick to embrace and work towards a paradigm shift that allows learners the flexibility of gaining knowledge. Higher Education 4.0 is all about preparing these new generation of 'digital connoisseurs' the skills, methods, learning and knowledge for the fast paced future they will live in.

In summary, the new Higher Education 4.0 is all about the students and these students' future teachers (the student teachers). These students now have the autonomy to charter their own course of study, they want new experiences to be ready for their future, but more importantly, education to them must be flexible enough to give them room for different learning approaches and to achieve their goals of choice. Technology plays an important role in all this - for the educators and those to be educated. The shift in learning is no more what was experienced by their parents and grandparents. These new generation of students must be ready to adapt to the ever changing work landscape. Technology is part of their everyday lives. However, in any attempt to be ready for $\mathrm{H} E$ 4.0, the perspectives of these students and those affected by it must also be sought. They must be involved and have the liberty to voice how they want their learning 
experiences to look like. However, in the end - universities must be ready - to adapt, to transform, to reform, and to embrace everything technology.

\section{Acknowledgement}

The paper presented here is a part of a larger research activity looking at the readiness of higher education towards H.E. 4.0, which is supported by the Fundamental Research Grant Scheme (FRGS) from the Ministry of Higher Education Malaysia [grant number: FRGS/1/2018/SSI09/UPSI/02/21]. Special thanks go to the Editors of this journal and the Reviewers of this paper who have unselfishly expanded their time to provide helpful comments and suggestions.

\section{References}

Abdul Hamid, M. S., Islam, R., \& Noor Hazilah, A. M. (2014) Malaysian graduates' employability skills enhancement: An application of the importance performance analysis. J. Global Business Advancement, 7(3), 181-197.

Altbach, P. G., Reisberg, L., \& Rumbley, L. E. (2019). Trends in global higher education. Rotterdam, The Netherlands: UNESCO Publishing.

Anane, E. (2014) Pre-service teachers' motivational orientations and the impact of self-regulated learning on their academic achievement: A mixed method study (PhD thesis). Retrieved from http://etheses.dur.ac.uk/10985/

Arends, R. (2014). Learning to teach (10 th ed). New York: McGraw-Hill Education.

Cornell University, INSEAD, and WIPO. (2015). The Global Innovation Index 2015: Effective innovation policies for development, Fontainebleau, Ithaca, and Geneva. Retrieved from https://www.wipo.int/edocs/pubdocs/en/wipo_gii_2015.pdf

Dadios, E. P., Culaba, A. B., Albert, J. R. G., Paqueo, V. B., Orbeta Jr. A. C., Serafica, R. B., Badala, A. A., \& Bairan, J. C. A. C. (2018). Preparing the Philippines for the fourth industrial revolution: A scoping study. Retrieved from https://pidswebs.pids.gov.ph/CDN/PUBLICATIONS/pidsdps1811.pdf

Darling-Hammond, L., Flook, L., Cook-Harvey, C., Barron, B., \& Osher, D. (2019). Implications for educational practice of the science of learning and development. Applied Developmental Science. Advance online publication. doi:10.1080/10888691.2018.1537791

Gaertner, M. N., Conley, D. T., \& Stolz, P. G. (2016). On Track: Redefining Readiness in Education and the Workplace. Retrieved from https://www.pearsoned.com/wpcontent/uploads/RINVN9943_RedefiningReadiness_PK_Final_020116_HR.pdf

Gardner, H. (2011). Frames of mind: The theory of multiple intelligences. New York: Basic Books.

Goh, P. S. C. (2019a). Preschool Teachers' Perspectives on Using English Language to Teach. GEMA online Journal of Language Studies, 19(4), 346-362. doi:10.17576/gema-2019-1904-18

Goh, P. S. C. (2019b). Implementing Narrative-pedagogical approaches in a Teacher Education Classroom. The Qualitative Report, 24(7), 1731-1746. Retrieved from https://nsuworks.nova.edu/tqr/vol24/iss7/14

Goh, P. S. C., \& Blake, D. (2015). Teacher preparation in Malaysia: Needed changes. Teaching in Higher Education, 20(5), 469-480. doi:10.1080/13562517.2015.1020780

Goh, P. S. C., \& Wong, K. T. (2015). Exploring the challenges for teacher educators. Journal of Research, Policy \& Practice of Teachers and Teacher Education, 5(1), 37-45. 
Goh, P. S. C., \& Matthews, B. (2011). Listening To the Concerns of Student Teachers In Malaysia During Teaching Practice. The Australian Journal of Teacher Education, 36(3), 92-103. doi:10.14221/ajte.2011v36n3.2

Goh, P. S. C., \& Canrinus, E. T. (2019). Preservice Teachers' Perception of Program Coherence and its Relationship to their Teaching Efficacy. Pertanika Journal of Social Science \& Humanities, 27(T2), 27-45.

Goh, P. S. C., \& Wong, K.T. (2014). Beginning teachers' conceptions of competency: Implications to educational policy and teacher education in Malaysia. Educational Research for Policy \& Practice, 13(1), 65-79. doi:10.1007/s10671-0139147-3

Goh, P. S. C., Canrinus, E. T., \& Wong, K. T. (2019). Preservice teachers' perspectives about coherence in their teacher education program. Educational Studies. Advanced online publication. https://doi.org/10.1080/03055698.2019.1584856

Jackman, W. M. (2018). Switching from traditional to blended learning at university level: Students' and lecturers' experiences. International Journal of Learning, Teaching and Educational Research, 17(5), 1-14. doi:10.26803/ijlter.17.5.1

Karal, H., \& Cebi, A. (2012). Views on modular assessment and evaluation process in distance education. Procedia - Social and Behavioral Sciences 46, 2073-2077.

Machado, C. (2007). Developing an e-readiness model for higher education institutions: Results of a focus group study. British Journal of Educational Technology 38(1), 72 82. doi:10.1111/j.1467-8535.2006.00595.x

Malaysia Education Blueprint 2013-2025. (2018). 2017 Annual Report. Putrajaya: Ministry of Education Malaysia.

McCowan, T. (2016) Three dimensions of equity of access to higher education. Compare: A Journal of Comparative and International Education, 46(4), 645-665, doi:10.1080/03057925.2015.1043237

Menon, S. (2019, December 13). Lifelong learning. The STAR Online. Retrieved from https://www.thestar.com.my/news/education/2015/12/13/lifelonglearning\#MW7MP2j2xx3xyGrt.99

Mustafa, Z. (2019, January 23). Importance of academia-industry linkages. New Straits Time. $\quad$ Retrieved from https://www.nst.com.my/education/2019/01/453582/importance-academiaindustry-linkages

Phelps, A., \& Vlachopoulos, D. (2019). Successful transition to synchronous learning environments in distance education: A research on entry-level synchronous facilitator competencies. Education and Information Technologies. Advanced online publication. doi:10.1007/s10639-019-09989-x

Prensky, M. (2001). Digital natives, digital immigrants. On the Horizon, 1 - 6. Readiness for the Networked World. (n.d). Retrieved from https://cyber.harvard.edu/readinessguide/guide.pdf

Rozana, S. (2017, January 21). Tertiary education redesigned. New Straits Times. Retrieved from https://www.nst.com.my/news/2017/03/206101/tertiaryeducationredesigned

Ruban, A. (2017, June 15). Minister: More than 5,000 MNCs adopted Industry 4.0. The Malay Mail online. Retrieved http://www.themalaymailonline.com/malaysia/article/minister-more-than5000-mncs-adopted-industry-4.0\#ug8Iz8qmE2iLVDcj.99

Salmon, G. (2019). May the fourth be with you: Creating Education 4.0. Journal of Learning for Development, 6(2), 95-115. 
Schwab, K. (2015). The Fourth Industrial Revolution: What it means, how to respond. Retrieved from https://www.weforum.org/agenda/2016/01/the-fourthindustrial-revolution-what-it-means-and-how-to-respond/

Shenglin, B., Simonelli, F., Ruidong, Z., Bosc, R., \& Li, W. (2017). Digital infrastructure: Overcoming the digital divide in emerging economies. Retrieved from https://www.g20-insights.org/wpcontent/uploads/2017/05/Digital_Overcoming-Digital-Divide-II.pdf

The world is changing. (2018). Retrieved from https:// www.weforum.org/agenda/2018/01/the-world-is-changing-here-show-companies-must-adapt/

Thompson, K. V., Nelson, K. C., Marbach-Ad, G., Keller, M., \& Fagan, W. F. (2010). Online interactive teaching modules enhance quantitative proficiency of introductory biology students. CBE life sciences education, 9(3), 277-283. doi:10.1187/cbe.10-03-0028 